\author{
Sosyal Bilimler Dergisi \\ Cilt 7 Sayı $14 \bullet$ Aralık 2017 \\ Makale Gön. ve Onay Tar.: 24.10.2017-25.10.2017
}

\title{
KAZAN TATAR TÜRKLERINDE MASAL ANLATMA GELENEĞI*
}

\author{
Folktale-Telling Tradition Among Kazan Tatar Turks
}

\author{
Mustafa GÜLTEKİN**
}

\begin{abstract}
$\ddot{O} Z$
Türk halk edebiyatı ürünleri içerisinde masallar gerek içerik ve konu özellikleri, gerekse işlevleri bakımından önemli ürünlerdir. Bu özelliklerinden hareketle masallar, Türkiye sahast üzerinde olduğu kadar Türk Dünyasında da çeşitli bilimsel yöntemler kullanılarak incelenmekte, hem sözlü kültür ortamindan derlenen hem de Türk lehçe ve şivelerinden Türkiye Türkçesine aktarlan metinler Türkiye'de yayımlanmaktadır. Bu çalışmalar; Türk boyları arasında ortak kültürel mirasin ve belleğin, ortak duyuş ve düşünüs tarzının, ortak hayal dünyasının gelecek kuşaklara aktarllabilmesi bakımından önemli bir yere sahiptir. Özellikle, halk bilgisi ürünlerinin yaratıldıklarl sosyal çevre ve şartların, yaratım ve aktarım bağlamına göre kazandlkları işlevlerinin, daha genel bir ifadeyle anlatı geleneklerinin araştırllması ve incelenmesi, elimizde bulunan metinlerin anlaşılması bakımından önemli veriler sunacak niteliktedir. Bu makalede, Türk Dünyası çalışmalarına katkı sunmak amacryla Kazan Tatar Türklerinde masal anlatma geleneği incelenmiştir. Makalede öncelikle gelenek ve masal anlatma geleneği kavramsal olarak tartışılmış, daha sonra da Kazan Tatar Türklerinde masal anlatma geleneği masal anlatıcllarl, dinleyiciler, icra mekânilyeri ve zamanı, masal metinleri alt başlıklarına ayrllarak değerlendirilmişstir.
\end{abstract}

Anahtar Sözcükler: Masal, Gelenek, Kazan Tatar Türkleri, Anlatıcl, Dinleyici.

\begin{abstract}
Folktales are important products in Turkish Folk Literature, in terms of their content and subject characteristics and functions. Based on these characteristics, Turkish world folktales as much as they are on the field of Turkey are examined using various scientific methods and texts that translated from Turkish dialects to Turkish are published in Turkey and compiled from oral culture context. These studies, the common cultural heritage and memory of the Turkish tribes has an important place in common sense and way of thinking in that the common dream world can be passed on to future generations. Especially, research of the context in

*Bu makale Tataristan Masalları Üzerinde Bir Araştırma (Gültekin, 2010) başlıklı doktora tezinden

hareketle hazırlanmıştır.

**Yrd. Doç. Dr., Gaziantep Üniversitesi, mgultekin@gantep.edu.tr
\end{abstract}


which folklores are created and the functions of the folklore according to the context of creation and narration, more explicitly, researching narrative traditions will be important for understanding the folktale-texts. In this article researched folktale telling tradition among Kazan Tatar Turks. In this article, the tradition and tradition of folktale-telling are conceptually discussed and folktale-telling, folktale teller and his audiences, context of storytelling event, time and place of telling are examined among Kazan Tatar Turks.

Keywords: Folktale, Tradition, Kazan Tatar Turks, Folktale-Teller, Audience.

\section{GíRIş}

Halk bilgisi ürünleri, belirli bir gelenek çerçevesinde yaratılır ve yine bu gelenek çerçevesinde kuşaklar arasında aktarılır. Bu nedenle halk bilgisi ürünlerinin temel özelliklerinden birisi, geleneğe bağl1lık (Yıldırım, 1998: 68; Ekici, 2007: 12) olarak kabul edilmektedir. Buradan hareketle halk bilgisi ürünlerinin incelenmesinde, o ürünlerin yaratım ve aktarım süreçlerini belirleyen, etkileyen, yönlendiren geleneğin bilinmesi büyük bir öneme sahiptir. Halk edebiyatı ürünlerinden biri olan masallar da diğer halk bilgisi ürünleri gibi belirli bir gelenek çerçevesinde yaratılır ve aktarılırlar.

$\mathrm{Bu}$ makalede, masal araştırmalarında sadece masal metinlerinin çeşitli açılardan incelenmesinin yeterli olmadığı, masalların yaratım ve aktarımını belirleyen geleneğin merkeze alınarak incelenmesi gerektiği düşüncesinden hareketle Kazan Tatar Türklerinde masal anlatma geleneği, masal anlatma geleneğini oluşturan masal anlatıcısı, masal anlatma yeri/mekânı, masalların dinleyicisi ve masal metinleri başlıkları altında incelenmiştir.

Gelenek terimi, çeşitli bilim insanları tarafindan ele alınmış ve tanımlanmıştır. Bu tanımların bir kısmı terimin kökeninde yer alan "gel-" fiilinden hareketle "eskiden gelen, atalardan gelen" sözcüklerini kullanarak, terimi tanımlamaya çalışmıştır. Sedat Veyis Örnek (2014: 178) "Bir toplumda kuşaktan kuşağa geçen kültür kalttları = (miraslart), alışkanlıklar, bilgiler, beceriler, davranışlar vb. gelenekler içinde yer alırlar." şeklinde belirgin bir şekilde "kalı", "miras" kavramlarını kullanarak geleneklerin eskiliğine vurgu yapar ve geleneklerin "nitelikleri bakımından genellikle tutucu" (Örnek, 2014: 179) olduklarını ifade eder.

Metin Ekici, gelenek nedir sorusuna verilen cevapları genel olarak değerlendirdikten sonra; "Eskiden beri devam edip gelen, gayri resmi yol ve yöntemlerle kazanilan ve kuşaktan kuşağa aktarılan ve zamanın ihtiyaçlarına göre her kuşakta belli ölçüde bireysel yaratıclliğa ve değişmeye ve de gelişmeye izin veren bilgi, hareket ve materyal ürünleri üretme ve kullanma tarzldır." (2008: 34) şeklinde bir tanımlama yapar. Ekici'nin tanımında dikkat çeken husus, gelenek kavramının süreklilik özelliğini ön plana çıkaracak bir değerlendirme yapılmasıdır. "Eskiden beri devam edip gelme", "gayrı resmi yol ve yöntemlerle kazanılma ve 


\section{0 / Mustafa GÜLTEKIN}

aktarılma", "bireysel yaratıcılığa izin verme" vb. ifadeler geleneğin, sadece geçmişle ilgisini değil, günümüz ve gelecekle olan bağını göstermesi bakımından önemlidir.

Gelenek teriminin tanımlanması, anlatı geleneği ve doğal olarak da masal anlatma geleneğinin ele alınmasını da doğrudan etkileyecektir. İlhan Başgöz'ün, "Masal, anlaticl, dinleyici ve geleneksel masaldan kurulu bir dengedir." (1988: 29) şeklindeki tespiti de bunu doğrular niteliktedir. Selami Fedakâr, Özbek masal anlatma geleneğini "anlatıcl, dinleyici, anlatma yeri, zamanı ve masal metni gibi unsurlardan" (2011: 113) hareketle ele almış ve değerlendirmiştir. Ekici'nin yukarıda verilen tanımı ile Başgöz ve Fedakâr'ın görüşleri çerçevesinde masal anlatma geleneğini ele aldığımızda, sözlü kültür ortamında nesiller arasında aktarılan masalları, bu masalları yaratan ve aktaran masal anlatıcılarını, masalları dinleyen dinleyici kitlesini, masalların anlatım yeri ve zamanı gibi unsurları bir bütün hâlinde ele almak gerektiği görülmektedir.

Masal anlatıcıları, masalı yaratan, aktaran veya sosyal çevre ve şartların değişmesine göre yeniden yaratan kişilerdir. Geleneğin sürekliliğgi ve nesiller arasındaki aktarımı da masal anlatıcıları tarafından sağlanmaktadır. Türk masal anlatıcıları hakkında son yıllarda yapılan çalışmalarda (Başgöz 1988; Boratav 1988; Sakaoğlu, 1999a, 1999b; Şimşek, 2002, Şenocak 2002, Alptekin 2005; Aça, 2007a, 2007b, Arslan 2008; Sarıtaş 2009; Önal, 2011; Fedakâr, 2011, Ergun, 2014; Gültekin, 2014) masal anlatıcılarının özellikleri, masal anlatımına etkisi, anlatıcıların yetişmesi, anlatıcılarla ilgili çeşitli inanış ve kabuller değerlendirilmiştir.

Masal anlatma geleneği içerisinde ikinci olarak değerlendirilmesi gereken unsur masalların dinleyicileridir. Masal anlatma eyleminin gerçekleşebilmesi için anlatıcı ve dinleyicilerin, bir arada olması ve karşılıklı iletişim içerisinde bulunulması gerekmektedir. Sözlü kültür ortamında dinleyicilerin tutumunun anlatıcıya etkisi (Başgöz 1986; Alptekin 2005) ve geleneksel olarak icranın oluşumuna katkısı da anlatının şekillenmesini de sağlamaktadır.

Masal anlatma geleneğini belirleyen unsurlardan üçüncüsü ise masal metnidir. Son olarak da masalların anlatıldığı yer/mekân ve anlatma zamanıdır. Bütün bu unsurların bir araya gelmesi, masal anlatma geleneğini oluşturmaktadır.

Kazan Tatar Türklerinde masal anlatma geleneğini de buradaki tespitlerimize göre masal anlatıcıları, masal dinleyicileri, masal anlatma yeri/mekânı ve zamanı ve masal metni başlıkları altında değerlendireceğiz.

\section{Masal Anlatıcıları:}

Bir ürünü, bir anlatıyl, bir sanat eserini, genel olarak da bir geleneği tanımanın, tanımlamanın, anlamanın ve anlamlandırmanın ilk ve en önemli adımı, o geleneği veya ürünü yaratan kişilerin belirlenmesi ve incelenmesidir. Masal anlatma geleneği içerisinde de masalları, yaratan ve geleneği temsil eden anlatıcıların 
dikkatle değerlendirilmesi gerekmektedir. Sanatçı veya yaratıcının, anlatıcının göz ardı edilmesi, ortaya çıkan ürüne odaklanılması eksik bir değerlendirmenin yapılması neden olacaktır.

Anlatı ve anlatıcı arasındaki ilişki üzerine Metin Ekici tarafından yapılan araştırmada, tarihsel olarak belirli tipte bir anlatıcıya sahip olan ürünlerde değişimin meydana geldiği tespit edilmiştir. Ekici bu incelemesinde, masal anlatıcılarıyla ilgili olarak "“Masallarda, mitik yaratmaların olağanüstü ve fantastik özellikleri insan ve insanüstü kahramanlara bağll olarak anlatılmaya başlanırken, bu anlatmaların yer ve zamana bağll olmadan ve de belli bir anlatıcı tipine bağlı olmaksızın anlatılır olmaları söz konusu olmuştur. Bu anlatmaların kendilerine ait bir tür geleneği oluşmakla birlikte, belli bir anlatıcı grubuna bağlı bir gelenek oluşturmaları söz konusu değildir." (2006: 87) değerlendirmelerini yapar.

Ekici'nin tespitlerine göre masalların, belirli tipte bir anlatıcısı yoktur. Geleneğe bakıldığında bazı anlatıcıların, masalı diğer insanlara göre daha başarılı bir şekilde anlatabildiği, bu yönüyle toplum içerisinde tanındığı görülmektedir. Ancak, masal anlatıcılarının, destan anlatıcıları/destancılar veya halk hikâyesi anlatıcıları/âşıklar gibi bir özelliğe sahip olmadıkları anlaşılmaktadır. Bu durum Kazan Tatar Türkleri için de geçerlidir. Kazan Tatar Türklerinde masal anlatıcıları; "Ekiyetçé (Masalcı)" veya "Ekiyet Söylevçé (Masal Anlatıcısı)" olarak adlandırılmaktadır. Konuyla ilgili araştırmasında Lenar Camaletdinov'un; Pek çok millette masal anlatımını kendisinin sanatı olarak kabul eden insanlar var. Ancak Tatarlarda profesyonel masal anlatıcılarının olup, olmadığını kesin olarak bilmiyoruz. Gerçi, I. Ramiyev bir çalışmasında Bulgarlarda masal anlatıcılarının yarışmasından bahsetmektedir. Ĕger gerçekten de böyle yarışmalar düzenleniyorduysa, ona katılanlar profesyonel masal anlatıcılarıdır diye düşünmek gerekir. Ancak, ne yazık ki yazar kendi görüşünü ispatlamak için herhangi bir delil göstermiyor. Diğer Türk boylarında profesyoneller olduğuna göre Tatarlarda da olduğunu kabul etmek elbette mümkündür. Ama bize göre, çok eskiden yerleşik hayata geçmiş ve yazll kültüre, kitaba sahip bir halk olduğundan Tatarlarda profesyonel masal anlatıcılarının olmaması da çok kuvvetli ihtimaldir." (1988: 5-6) sözleri ile Tatar masal anlatıcıları ile ilgili görüşlerini dile getirmiştir. Camaletdinov, "profesyonel” sözü ile kanaatimizce, geçimini masal anlatımı ile kazanan, mesleği sorulduğunda "masal anlatıcısıyım" cevabını veren bir anlatıcıyı kastetmektedir. Bu çerçeveden değerlendirildiğinde, masal anlatarak geçimini temin etme eyleminin genel bir özellik ve yaygın bir uygulama olmadığını söylemek mümkündür.

Masal anlatıcısı, masalı yaratan veya aktaran kişidir. Sanat seviyesi bakımından bir sınıflandırma olan bu yaklaşım, diğer Türk boylarında da görülmektedir. Özbek destan anlatıcıları da bu özelliklerine göre "Yaratıcı Masal Anlatıcıları" ve "Aktarıcı Masal Anlatıcıları" (Fedakâr, 2011: 119) olarak değerlendirilmekte ve sınıflandırılmaktadır.

Kazan Tatar Masalları ile ilgili önemli araştırmaları bulunan Lenar Camaletdinov, usta bir masal anlatıcısında bulunması gereken; "1. Masalı içten bir 


\section{2 / Mustafa GÜLTEKIN}

şekilde sevmek, 2. Çok iyi bir hafiza, 3. İlginç ve sürükleyici bir şekilde anlatma yeteneği, 4. Masallart eskiden beri anlatiyor olmak." (Camaletdinov, 1988: 11) özelliklerini belirlemiştir. Linda Degh de masal anlatıcısının belleğinde birden fazla masalı ve repertuvarına ait bireysel parçaları zihninde tutmasının, anlatıcının sanatını icra edebilmesi bakımından önemli olduğunu belirtir (Degh, 1989: 166).

Kazan Tatar Türklerinin masalları üzerine araştırmalar yapan bilim insanları usta masal anlatıcısı olarak tanınan ve tanımlanan anlatıcıların biyografilerine de çalışmalarında yer vermişlerdir.

Gomer Razin, Tatar masallarıyla ilgili ilk ve önemli çalışmalardan biri olan "Halık Ekiyetleri (Halk Masalları)" adlı çalışmasının giriş kısmında, masal anlatıcılarının önemini ele aldıktan sonra, derleme yaptığ 1 Minhac Hemidullin, Möhemmetşa Devleştin, Söngat Sibayev, Aleksandr Varvarin ve Fedor Blinov hakkında bilgi vermiștir (Razin, 1940: 9-11). Beşirov, tarafindan yayımlanan "Tılsımnar Dönyasında (Sihirler Dünyasında)" adlı makalede de Minhac Hemidullin, Möhemmetşa Devleştin ve Heyrettin Höseyinov adlı masal anlatıcıları hakkında bilgi verilmiştir (Beşirov, 1965: 243-247). Lenar Camaletdin de Mincamal Gulova adlı usta bir kadın masal anlatıcısını bir makalesinde ele almış ve sanatıyla ilgili değerlendirmelerde bulunmuştur. (1977: 139-146).

Masal anlatıcılar ile ilgili üzerinde durmak istediğimiz bir başka konu da anlatıcıların cinsiyetidir. Türkiye'de genel olarak masal anlatıcılarının kadın olduğu düşüncesi hakimdir. Erkek anlatıcılardan da masal derlenmekle birlikte, türün anlatıcısının kadın olduğu fikri veya kabulü, yapılan bilimsel çalışmalar bağlamında değerlendirildiğinde, yani masal derlenen kaynak kişilerin cinsiyeti bağlamında ele alındığında anlatıcıdan çok derleyicinin cinsiyetine bağlı olarak derleme süreçlerinin şekillendiği görülmektedir. Bu konuda Bilge Seyidoğlu (1975) ve Saim Sakaoğlu (2002) tarafindan yapılan çalışmalarda anlatıcıların cinsiyetine bakmak bir fikir vermesi bakımından yararlı olacaktır. Seyidoğlu tarafından yayımlanan çalışmada daha çok kadın anlatıcılardan derlemeler yapıldığı; Sakaoğlu tarafindan yayımlanan çalışmada ise çoğunlukla erkek anlatıcılardan derleme yapıldığı görülmektedir.

Kazan Tatar Türklerinde masal anlatıcılarının cinsiyeti üzerine yapılmış bir bilimsel çalışma bulunmamaktadır. Ancak, yukarıda işaret ettiğimiz gibi bir kadın masal anlatıcısını ele aldığı yazısında Lenar Camaletdinov'un "Tatar masallarının yayınlandığl en geniş ve güvenilir kaynaklar olarak kabul edilen iki ciltlik bilimsel yayına (I. Cilt 1946, II. Cilt 1956) bakttğımızda, masal derlenenler arasında bir tane bile kadın adina rastlamiyoruz. Fakat bu bizde kadın masal anlatıclarınin bulunmadı̆̆ anlamina gelmez. Son yillardaki derleme gezilerinden anlaşıldiğına göre şimdiki masal anlatıcılarınin üçte birini kadınlar oluşturmaktadır." (1977: 139) şeklindeki tespitleri, masalların genellikle erkek anlatıcılardan derlendiğini, ancak dönemsel olarak son zamanlarda yapılan derlemelerle kadın anlatıcıların sayısında belirgin bir artış olduğunu göstermektedir. 
Masal anlatma geleneği ile ilgili olarak üzerinde durmak istediğimiz bir başka konu da masal anlatıcılarının yetişmesi ve masal repertuvarını öğrenmesi sürecidir. Destan ve halk hikâyelerini anlatan icracıların, usta-çırak ilişkisi içerisinde repertuvarı öğrendiği veya anlatımda ustalaştığı görülmektedir (Çobanoğlu, 2000: 197; Reichl, 2002: 56-95; Artun, 2011: 61-63). Masal anlatıcılarının yetişmesinde destan ve hikâye anlatıcılarının yetişmesinde görüldüğü şekliyle bir usta-çırak ilişkisinden söz etmek mümkün değildir. Masal anlatıcıları, sözlü kültür ortamında dinleyici olarak katıldıkları anlatımlar sırasında masalları öğrenirler ve anlatırlar. Masal anlatımının devam etmesi, bir taraftan yeni masal anlatıcılarının yetişmesini, diğer taraftan repertuvarın yayılmasına ve yeni masalların yaratılmasına imkân tanıyacaktır. Anlatımın ortadan kalkması durumunda yeni anlatıcıların da yetişme imkânı kalmayacaktır. Lenar Camaletdinov, bu durumu şöyle ifade etmektedir:

"Masallar halk arasında anlatılmadığından, yeni masal anlatıcıları yetişmiyor, mevcut olanlar da olgunlaşamıyor. Derleme gezileri sırasında rastladığımı masal anlatıcıların çoğunluğu, genellikle masalları gençliklerinde ögrenen ve bugüne kadar hafizalarında saklayan yaşlı kişilerdi. Şimdi böyle anlatıcılara rastlamak gittikçe zorlaşıyor. Hatta 'masall,' yerlerde bile siradan bir kişiye ancak rastlanıyor. Fakat çoğunlukla o kişinin masal anlatıcısı olduğunu köylüleri de bilmiyor." (1988: 12).

Masal anlatıcılarının temel özelliklerinden birisi, kişisel özelliklerinin masal metinlerine yansımış olmasıdır. Bu durum, masal ve masal anlatıcısı arasındaki ilişkinin ne kadar önemli olduğunu göstermektedir. Gomer Razin, "Masalda, masal anlatanın, masalcının çok büyük rolü var. Masal anlatıcısının hangi devrin, hangi sosyal tabakanın insanı olduğu, dünya görüşü, ustalığı ve bunun gibi başka özellikleri masala büyük etki ediyor. Mesela, büyük çoğunluğu çiftçi kitleleri arasından çıkan bizim masallarımızda (Bu kitapta yayınlan masallardan özellikle de Möhemmetşa Devletşin'den derlenen masallarda) padişahlar, çoğunlukla çiftçilerin arasında, köyde, aynı çiftçiler gibi yaşıyorlar. Onlar masal içerisinde gerek olan şartlar yerine getirildiğinde, fakir çiftçi oğluna veya yiğit bir avcıya kendi kızlarını veya padişahlı̆̆ının yarısını vermeye de olmayacak iş diye bakmıyorlar.

Her masal anlatıcısl, masalı kendi hisleri, kendi dünya görüşü ile süsler, kendi anlayışına ve hatta çoğu zaman dinleyicilerin nasıl olduğuna göre de kahramanların karakterlerine çeşitli sıfatlar ekler; masala kendi yaşadığ çevrede kullanılan atasözleri, deyimler ve özlü sözler ekler. Böylece masal, kendi temel özelliklerini değiştirmeden korurken de masal anlatıcısının yaratmasına dönüşür. İste bu nedenle folklor eserlerini derlerken, onun ne zaman, nerede, kim tarafindan anlatıldı̆̆ını göstermek, anlatıcının dilindeki özelliklerin tamamen korumak temel şart olarak konmuştur. " (Razin, 1940: 6-7).

Mark Azadovski de bu duruma işaret etmiş ve “..masalcının hayat deneyimleri, gözlem yeteneği, tuttuğu iş ve kişisel niteliklerinin masalın yeniden söylenmesinde büyük katkıları olduğunu..” ifade ettikten sonra, masal anlatıcılarının 


\section{4 / Mustafa GÜLTEKIN}

dinî inanışlarının, mesleklerinin masala etkisini ayrıntılı olarak, incelemiştir (Azadovski, 2002:53).

Masal anlatıcısını etkileyen unsurların başında dönemin siyasi koşulları gelmektedir. Özellikle Sovyetler Birliği dönemindeki siyasal baskılar göz önüne alındığında anlatıcılar olduğu kadar derlemeciler ve bilimsel araştırma yapan bilim insanlarının da bu süreçten etkilendiği görülecektir. Moskava'nın sistemli ve planlı bir şekilde büyük bir Sovyet toplumu yaratma çabaları bunda etkili olmuştur. $\mathrm{Bu}$ konudaki çalışmalarla ilgili olarak 10 Temmuz 1939 tarihli "Kızıl Tatarstan (Kızıl Tataristan)" gazetesinde "Ekiyetçéler Moskvadan Kayttılar (Masal Anlatıcıları Moskova'dan Döndüler)" adıyla yayınlanan bir habere burada yer vermek yerinde olacaktır.

"Masal anlatıcilarinin ve halk cirlarin icra edenlerin Moskova'da düzenlenen bütün Sovyet halklarl seminerine katılan delegeler bu günlerde Moskova'dan döndüler. Seminere Tataristan'dan katılan masal anlaticısı Minhac Hemidullin (Téleçé Rayonu, Maksabaş Köyü) ve Gani Musin (Tatpişçetorg'un 18 'inci numaralı mağaza iş̧̧isi) yoldaşlar, Kızıl Başkentin kendilerinde bıraktı̆̆ etkiyle ilgili olarak görüstüler. Onlar Moskova'ya hayran oldular. Moskova'nın müzelerinde, tiyatrolarinda, metroda, Moskova-Volga kanalinda bulunmak onlarda büyük bir etki bırakmış." (Kızıl Tatarstan, 1939: 2).

Gazetede yer alan bu haber, Sovyetler Birliği yönetiminin ideolojinin yaygınlaştırılması için masal anlatıcılarından da istifade etmeyi düşündüğünü ve düzenlenen seminere, Tataristan'dan masal anlatıcılarının da katıldığını göstermektedir. Minhac Hemidullin'in en meşhur Tatar masal anlatıcılarından biri olduğu da dikkate alındığında, seminere Tataristan delegesi olarak katılmasının nedenleri daha iyi anlaşılacaktır. Nitekim, "Yeş Stalinçı (Genç Stalinci)" adlı gazetenin Haziran 1940 tarih, 71 (1800) nolu sayısında, Minhac Hemidullin'in "Lenin ve Stalin"e ithaf ettiği bir masal metni yayımlanmıştır.

\section{Masal Dinleyicileri:}

Masal anlatma geleneği içerisinde dinleyicilerin de önemli bir yeri vardır. Anlatma hadisesinin gerçekleşmesi için öncelikle bir anlatıcıya ve dinleyici kitlesine ihtiyaç vardır. Dan Ben-Amos, bağlam merkezli bir halk bilimi çalışması için, üç boyutlu bir yaklaşımın benimsenmesi gerektiğini, bu üç boyutun, "Bireysel Boyut (Antatıci/İcract-Oyuncu), b. Sosyal Boyut (Dinleyici/İzleyici), c. Anlatı Söz Boyutu (Anlattlan)" (Ekici, 2007: 130; Ben-Amos, 2007: 238) olduğunu söyler. İlhan Başgöz'ün hikâye anlatımında dinleyicilerin etkisi ile tespitleri (1986: 49-64) masal anlatımı için de geçerlidir.

Anlatım hadisesi genellikle dinleyicilerin talepleri doğrultusunda gerçekleşmektedir. Dinleyiciler, sadece anlatımın gerçekleşmesini sağlamakla kalmaz, aynı zamanda anlatım anında masal anlatıcısını etkilemesi bakımından da 
dikkat çeker. Anlatıcı ve dinleyicinin karışlıklı etkileşimi ile anlatım süreci oluşur. Ayrıca dinleyicilerin; yaş, cinsiyet ve eğitim durumu gibi özellikleri, anlatım talebinin dinleyicilerden gelip gelmediği, anlatım sırasında anlatıcıdan etkilenip etkilenmedikleri gibi hususlar masal anlatıcısını etkilemektedir (Çobanoğlu, 2002: 265-316; Dorson, 2006: 77-80; Ekici, 2007: 128-131). Özellikle destan (Reichl, 2002: 119-123) ve halk hikâyesi (Başgöz, 1986: 57-58) anlatımında görülen anlatıcı dinleyici ilişkisi, masal anlatımında da benzer şekilde görülmektedir.

Anlatının uzaması veya kısalması, masal anlatımında anlatıcının formelleri kullanıp, kullanmaması da anlatıcının ustalığı kadar, dinleyicilerin anlatıya verdikleri tepkilere bağlı olarak da değişmektedir. "Masalcının icraya hazırlanırken veya icra anında, dinleyicilerin bazı olumsuz tavır ve davranışlar sergilemeleri, masalcının masal anlatma hevesinin kaçmasına, anlatım ortamının havasının bozulmasina, hatta masalcinin anlatmayl yartda kesmesine sebep olabilir." (Fedakâr, 2011: 132).

Masalların dinleyici kitlesi, o toplumda yaşayan herkes olarak kabul edilebilir. Dinleyici kitlesini belirleyen masalın anlatıldığı yer, anlatım zamanı ve amacıdır. Çocuğunu oyalamak, eğitmek veya hoşça vakit geçirmesini sağlamak isteyen bir annenin dinleyicisi çocuğu alacaktır. Herhangi bir işi yapmak için bir araya gelen ve belirli bir zamanda masal anlatmaya başlayan anlatıcının dinleyicileri de orada bulunan arkadaşları olacaktır.

Masal dinlemenin özel bir eğlence biçimi olarak rağbet gördüğü dönemde, dinleyicilerin ilgisi hakkında Lenar Camaletdinov'un bir kaynak kişinin anılarından hareketle aktardığı; "Gençler gündüz hangi hamamdan duman çıktığına bakar dururlar ve o hamamda Süleyman ağabeyin masalını dinlerler." (1988:7) şeklindeki ifadeler, Tatar masal anlatıcılarının ve dinleyicilerinin masala olan ilgisini göstermektedir.

Masal anlatma geleneğinin varlığını sürdürmesinde anlatıcılar kadar dinleyicilerin de etkisi vardır. Lenar Camaletdinov Kazan Tatar Türklerinde masal anlatma geleneğinin zayıflaması ile dinleyicilerin ilişkisini; "Şimdiki zamanda masal dinleme ihtiyact gittikçe azaliyor, çünkü halkın bugünkü estetik ve fikrî ihtiyaçlarını üst seviyeye ulaşan yazılı edebiyat ve sanat karşılamaktadır. Bunun yanından bilimsel ve teknik gelişmelerin yaşandiğı devirde, masallarda anlatılan olaylar dinleyicileri eskisi gibi etkisi altına almiyor, şaşırtmıyor." (Camaletdinov, 1988:12) sözleriyle açıklamakta, geleneğin yok olmasını dinleyicilerin masala olan ihtiyaçlarının azalmasına bağlamaktadır.

\section{Masal Anlatma Yeri/Mekânı ve Zamanı:}

Masal anlatma geleneğinin bir bütün olarak incelenmesinde anlatma yeri ve zamanı da önemli unsurlardır. 


\section{6 / Mustafa GÜLTEKIN}

Masal, tür özellikleri ve işlevleri itibariyle, masal anlatıcısının zamanının uygun olduğu ve karşısında dinlemeye hazır bir dinleyicinin bulunduğu herhangi bir zaman diliminde ve herhangi bir yerde anlatılabilecek bir türdür. Ancak, bazı Türk boylarında masalların anlatım zamanı ile ilgili inanç ve uygulamalar da bulunmaktadir.

Sibirya'da yaşayan Türk boylarında destan ve masal anlatım zamanı ve ortamı üzerine bir inceleme yapan Mehmet Aça;

"Güney ve Kuzey Sibirya Türklerinde tören ve hatta bir âyin havasinda gerçekleştirilen destan ve masal anlatımı, hangi amaçla gerçekleştirilirse gerçekleştirilsin, diğer bazı Türk topluluklarında da olduğu üzere, genellikle aksam ve gece saatlerinde yapılmaktadır. Özellikle destan anlatımının aksam gün batımından itibaren başlatılarak ertesi gün, gün doğarken bırakılması ya da güneş doğduktan sonra sürdürülmemesi, dışarıdan bakıldı̆̆ında, doğrudan aksam ve gece saatlerinin, insanların günlük islerini tamamlayıp dinlenmeye çekildiği, bir araya gelerek eğlendiği anlar olması ile açıklanabilir. Fakat, geleneğin yaratıcıları ve icracıları, destan ve masal anlatımı zamanının tayinini sadece günlük hayatın akışıyla değil, çeşitli inanışlar ve tabular çerçevesinde de biçimlendirmeye çalışmışlardır. Anlatım zamanını belirleyen yasaklar ve inanışlar, destan ve masal anlatımının günlük hayatın akışını olumsuz biçimde etkilemesini engellemeye yönelik çabaları destekler bir özellik arz etmektedir. Fakat, bu inanışlarla yasakları, sadece günlük hayatın akışını bozmamaya yönelik çabaları desteklemesi boyutuyla değil, zikredilen Türk topluluklarındaki destan ve masalın anlatılış amaçlarlyla da birlikte ele almak gerekmektedir. Ayrıca, Güney ve Kuzey Sibirya sahasi Türk topluluklarının masal ve destan anlatma geleneklerinde görülen bu tür inanış ve yasakların ortaya çıkısında, masal ve destan anlatımının geçmişte inanç dünyasına ya da kutsallara hitap eden törensel/âyinsel bir eylem gibi algllanmasının da önemli bir etkisinin olduğunu ifade etmek gerekmektedir." (Aça, 2007a: 13-14) sözleriyle, anlatım zamanıyla ilgili inanç ve uygulamalara işaret etmektedir.

Aça'nın bu tespitleri Türk boylarında, özellikle de Sibarya bölgesinde yaşayan Türk boylarında destan ve masal anlatımının önemiyle ilgili oldukça değerli bilgiler içermektedir. Ancak Kazan Tatar Türklerinin masal anlatma geleneği içerisinde böyle ayinsel özelliklerin en azından günümüzde var olmadığı görülmektedir.

Tatar masal anlatma geleneğinde masallar, genellikle kış mevsiminde ve geceleri anlatıldığı tespit edilmiştir. Masalların mevsimsel ve zamansal olarak bu tarz zaman dilimlerinde anlatılması, günlük yaşam ve ekonomik faaliyetler tarafından yönlendirilen veya belirlenen bir süreçtir. Lenar Camaletdinov'un Kazan Tatar Türklerinde masal anlatma yeri ve zamanı ile ilgili tespitlerini aktarmak ve bu tespitler üzerinde değerlendirmelerde bulunmak yerinde olacaktır:

"Masal anlatmanın belirli bir vakti ve yeri vardır. Elbette, sıkışık iş arasında, yazın sıcak günlerinde, çiftçinin masal anlatmak veya dinlemek için oturmaya vakti 
yoktur. Bu nedenle masal çoğunlukla uzun kaş gecelerinde anlatılır. Halk arasında, 'Gündüz masal anlatan adamı kurt yer.' şeklinde bir atasözü bulunmaktadır.' (1988: 7).

Camaletdinov'un bu tespitlerinden hareketle, Kazan Tatar Türklerinde işlerin yoğun olduğu yaz aylarında masal anlatacak vakit bulunmadığından, masallar uzun kış gecelerinde anlatıldığı görülmektedir. Buradaki en önemli tespit, Tatar Türkleri arasında kullanılan "Gündüz masal anlatan adamı kurt yer." ş̧eklindeki sözdür. Bu söz de göstermektedir ki, belki de derleme ve yayın faaliyetlerinden çok önce, Sibirya'da yaşayan Türk boylarında olduğu gibi, Kazan Tatar Türklerinde de masal anlatmanın kutsal bir anlamı vardı. Ancak günümüzde bu ifadede, vakti olmayan anlatıcının, kendisinden masal anlatmasını isteyen dinleyicilerine gösterebileceği en güzel gerekçe olarak da değerlendirilebilir.

Kazan Tatar Türklerinde, masal anlatılan mekânlar olarak; ev, hamam, medrese gibi belirli mekânların yanında, herhangi bir işi yerine getirmek üzere bir araya gelen insanların konakladığı veya dinlenmek için bulundukları yerler tespit edilmiştir (Camaletdinov, 1988: 7-11).

Askerlik ve mevsimlik işler için bir arada bulunan insanlar da bulundukları yerde masal anlatmaktadırlar. Oduncular, maden ocağında çalışanlar, balıkçılar da mevsimlik iş için bir araya geldiklerinde masal anlatarak, eğlenirler ve dinlenirler (Camaletdinov, 1988:10). Çalışmak amacıyla başka coğrafyalara gidilmesi ve burada geceleri masal anlatılması, Türk boyları arasında masalların yayılmasını da sağlamıştır. Masal anlatıcısı Safiulla Gabitov'un Özbekistan'a gidip demir yolu işçisi olarak çalıştığı dönemle ilgili olarak anılarından bahsederken masal anlatımı hakkında kullandığı şu sözler de bunu desteklemektedir: "Taşkent demir yolu yapılırken çalıştı̆̆ımda barakada çeşitti halklardan, Tatarlar ve Başkurtlar çoğunluktaydl. Biz her gün akşam olunca nöbetleşe olarak yarışa yarışa masal anlatıyorduk. Masalı ustalıkla anlatan kişiye barakadaki işçilerden bazıları şeker, bazllarl da para verirlerdi." (Camaletdinov, 1988: 11).

Sonuç olarak Tatar Türkleri arasında masallar genellikle uzun kış gecelerinde anlatılmaktadır. Bu durum, Tataristan'ın millî şairi Gabdulla Tukay'ın şiirlerine de yansımıştır. Tukay, "Kış Gecesi” adlı şiirinde,

"Kış̧ı kiçnén ozınlıgın sizmiyséz de

Enkegéznén söylegené ekiyet bérle"

(Annenizin anlattı̆̆ı masal sayesinde

Kış gecesininin uzunluğunu hiç fark etmiyorsunuz)"

ve, "Tugan Tél" adlı şiirindeki,

"Annarı tönner buyı ebkem hikeyet süylegen

(Onunla geceler boyu ninem masal analtmış)"

şeklindeki sözleri ile bu durumu ifade etmiştir (Camaletdinov, 1988: 6-7)

\section{Masal Metinleri:}




\section{8 / Mustafa GÜLTEKIN}

Masal anlatma geleneği içerisinde anlatıcı, dinleyici, icra ortamı çerçevesinde şekillenen sürecin neticesinde ortaya çıkan metin, yani masalın kendisi de burada değerlendirmek istediğimiz bir başka unsurdur. Daha doğru bir ifadeyle metin, bütün süreçlerin neticesinde ortaya çıkmış bir ürün ve doğal olarak o süreçlerin veya unsurların her birinden izler taşıyan bir bütünlüktür.

Masal türünün özellikleri, aynı zamanda metnin yaratım ve aktarımını da etkilemektedir. Geleneksel olarak sözlü kültür ortamında yetişen masal anlatıcıları, dinledikleri masalların özelliklerinden hareketle yeni masallar yaratabilmektedirler. $\mathrm{Bu}$ yaratım sürecinde, daha önceden yaratılmış olan masallar, birer örnek teşkil etmektedir.

Metin kavramı, doğrudan yazıya ve yazılı kültüre gönderme yapan bir kavramdır. Metnin böyle tanımlanmasını Jeff Todd Titon, şöyle değerlendirmektedir: "Bir metin modeli olarak edebiyat görseldir: okuma ve yazma edimlerine, sayfanın üzerindeki kelimelere işaret eder; bu ise metnin en dar yorumudur.” Titon bu açıklamasına, "Metin, daha geniş anlamda, dokunulanı, sözlü olanı, jestleri $v b$. içerir.” şeklinde devam ederek, metnin daha geniş bir anlamı olduğunu vurgulamaktadır (Titon, 2015: 273).

Masallar sözlü gelenekte yaratılan ve aktarılan halk bilgisi ürünleri olmasına rağmen, bazı masallar yazılı olarak yaratılmış ve sözlü geleneğe yazılı kaynaklar aracılığıyla yayılmışlardır. Bunun dışında sözlü gelenekte yaşayan masalların, yazarlar tarafindan edebî olarak işlenmesi ve okuyuculara sunumu da söz konusudur. Tatar Türklerinin millî şairi Gabdulla Tukay'ın veya Ziya Gökalp'ın sözlü gelenekteki masalları nazma çekmesi buna örnek olarak verilebilir (Sever, 2007; Atnur, 2009).

Sözlü olarak yaratılan ve sözlü gelenek içerisinde bir dinleyici karşısında anlatılan masallar ise bilimsel amaçlarla derlenip yazıya geçirildiğinde pek çok özelliğini yitirmektedir. Alan araştırması sonrası kayıtların deşifre edilmesiyle, incelenmeye hazır yazılı bir metin oluşmakla birlikte, anlatıma ait bazı hususlar bu yazılı metne yansımamaktadır. Şüphesiz, edebî bakımdan ve yapısal olarak değerlendirebilmek için yazılı bir metne ihtiyacımız var. Ancak, salt yazılı metne dönüştürülmüş bir anlatımı da bilimsel olarak anlamak, açıklamak ve yorumlamak imkânsız hâle gelmiş olmaktadır. Titon bu duruma "Folklor olarak nitelendirilen herhangi bir iletişim olayından meydana gelen metinler açıkça bir dönüştürme ve indirgemedirler." (Titon, 2015: 274) ifadeleriyle dikkat çekmektedir.

Halk bilimi araştırmalarında, özel olarak da masal araştırmalarında, metinlerin derlenmesi ve yazıya geçirilme süreci büyük önem kazanmaktadır. Tatar Türkçesinde derleme karşılığı olarak “yazıp almak” fiili kullanılmaktadır. İlk derlemeler genellikle bir anlatıcı tarafindan masal anlatılırken, anlatılanların elle kâğıda yazılması şeklinde yapılmıştır. Daha sonraları ise "stenografi" adı verilen yöntemle derlemeler yapılmıştır. Stenograf olan Halide Gatina'nın masalları anlatıcının ağzından çıktığı hızda yazabildiği Lenar Camaletdinov tarafından ifade 
edilmektedir. Teknolojik gelişmelerin sonucunda alan araştırmalarında önce ses kaydedici cihazlar, daha sonra da görüntü kaydedici cihazlar kullanılmaya başlanmıştır.

Tataristan'da derlenen masalların yazıya geçirilmesi sırasında sözel dokusunun ve bağlamın tamamen göz ardı edildiği görülmektedir. Bu durumda sözlü kaynaklardan, alan araştırması sonucunda derlenen metinler, yazılı metin özelliği kazanmakta ve kısmen de olsa metni yazıya geçirenin üslûp özelliklerini yansıtmaktadır. Derlemenin ve derlenen materyalin deşifresinin bağlam merkezli bir yaklaşımla yapılmaması, bu metinler üzerinde bağlama veya sözel dokuya ait bir değerlendirme yapma imkânı da sunmamaktadır.

Masal metinleriyle ilgili olarak burada tartışmak istediğimiz son husus, metinlere yayın aşamasında yapılan müdahaleler meselesidir. Sovyetler Birliği döneminde bilim adamı, aydın, sanatçı, yazar ve din adamları ya pantürkist ya da panislamist damgası vurularak sürgün edilmiş ve öldürülmüşlerdir (Mostafin ve Davutov, 1997; Galiullin, 1998). Bu dönemde, Türk boylarının halk bilgisi ürünleri yayınlanırken, metinlerde yer alan millî ve dinî unsurlar çıkarılmış ve metinlere müdahale edilmiştir. Bu durum Tatar halk bilgisi ürünlerinin yayınlanması için de geçerlidir. Ancak, Tatar halk bilgisi ürünleriyle ilgili olarak bilgi verilen kaynaklarda bu konuda herhangi bir açıklama bulunmamaktadır. Ancak yayımlanan metinlerde karşılaştı̆̆ımız bir örneği burada değerlendirmek metin yayınlarında müdahale edilen unsurlar hakkında bir fikir vermesi bakımından önemlidir. "Kece Bilen Büri (Keçi ile Kurt)" adlı masal metni, 1944 yılında çocuklar için küçük bir kitapçık olarak yayınlanmıştır. Bu yayında, kurt ile ayı karşılaştıklarında birbirleri ile "Esselamüaleyküm/Ve aleykümselam" şeklinde dinî usullere uygun olarak selamlaşmaktadırlar (1944:4). Ancak aynı metin, daha sonra bilimsel bir yayın olarak değerlendirilen "Tatar Halık Ekiyetleré" adlı kitapta yayınlanırken, selamlaşma şeklinin değiştirildiğini ve "Merhaba"ya dönüştüğünü görmekteyiz (1950: 14). Bu örnek de göstermektedir ki, Tatar masalları yayınlanırken dinî unsurlar masal metinlerinden çıkarılmıştır ve metinlere müdahale edilmiştir.

\section{SONUÇ}

Masal anlatma geleneğinin unsurları olarak değerlendirdiğimiz anlatıcı, anlatı (metin), anlatma yeri/mekânı ve zamanı ve dinleyiciyle ilgili verdiğimiz bilgilerden sonra Kazan Tatar Türklerinde masal anlatma geleneğiyle ilgili genel bir değerlendirme yapmanın yerinde olacağını düşünüyoruz.

Kazan Tatar Türklerinin masal anlatma geleneğinde, masal anlatıcıları "Ekiyetçé (Masalcı) veya "Ekiyet Söylevçé (Masal Anlatıcısı)" olarak adlandırılmaktadır. Tatar masalları üzerine yapılan ilk derlemeler genel olarak erkek anlatıcılardan yapılmıştır. Ancak, daha sonraki derlemelerde kadın masal anlatıcılarından da derlemeler yapıldığı görülmektedir. 


\section{0 / Mustafa GÜLTEKIN}

Kazan Tatar Türklerinde, masalların hemen her yerde ve genellikle kış mevsiminde akşam saatlerinde anlatıldığı görülmektedir. Ancak, bu zamanlar dışında da masalların anlatılabilmektedir. Türk boylarının bir kısmında tespit edilen inanış ve uygulamalar, Kazan Tatarlarında görülmemektedir.

Tatar masal metinlerinin derlenmesi ve yayınlanmasında sadece metni elde etmeye yönelik çalışmalar yapıldığı, metin dışında anlatı geleneği bakımından çok önemli olan bağlam ve sözel dokunun ihmal edildiği görülmektedir. Derlenen metinler yazıya geçirilirken, anlatıcı tarafindan kullanılan açıklamalara ve ara sözlere yer verilmediği gibi, siyasî yapı nedeniyle masal metinlerine müdahale edilmiş ve metinler, düzenlendikten ve bazı unsurlar metinlerden çıkarıldıktan sonra yayınlanmıştır.

\section{KAYNAKLAR}

“ALMAZ Batır, Bélen Korıç Batır.” Yeş Stalinçı. İyun 1940.

"Ekiyetçéler Moskvadan Kayttılar." Kızıl Tatarstan. No: 156 (5657), 10 Temmuz 1939, s. 2.

AÇA, Mehmet (2007a). "Destan ve Masal Anlatımı Zamanı ile Ortamını Belirleyen İnanışlar Nelerdir?" I. Uluslararası Türk Dünyası Kültür Kurultayı (9-15 Nisan 2006, Çeşme-İzmir) Bildiri Kitabı I. Ed. Fikret Türkmen, Gürer Gülsevin. Ankara: Ege Üniv. Yay, ss. 13-22.

AÇA, Mehmet (2007b). "Güney Sibirya Türklerinde Ava Destancı ve Masalcı Götürme Geleneği”. TÜBAR XXI/-Bahar, ss. 7-16.

ALPTEKIIN, Ali Berat (2005). “Türk Halk Anlatmalarında Yeni Unsurlar”. Türk Dili Dil ve Edebiyat Dergisi 642. (Haziran-2005), ss. 502-509.

ARSLAN, Mustafa (2008). Denizli Yöresinden Derlenmiş Masallar İncelemeMetinler. Denizli: Zirve Yayınları.

ARTUN, Erman. Asşıklık Geleneği ve Âşıl Edebiyatı Edebiyat Tarihi/Metinler. Adana: Karahan Kit.

ATNUR, Gülhan 2009). "Abdullah Tukay'ın Şiirlerinde Masal ve Efsane Unsurlar1.” Bilig. S.: 51, Güz 2009, ss. 1-12.

AZADOVSKİ, Mark (2002). Sibirya'dan Bir Masal Anası. Girişi Yazan ve İngilizce'den Çeviren: İlhan Başgöz. Ankara: Kültür Bak. Yay.

BAŞGÖZ, İlhan (1986). Folklor Yazıları. İstanbul: Adam Yay. 
BAŞGÖZ, İlhan (1988). "Masalın Anlatıcısı". Masal Araştırmalarl/Folktale Studies I. Haz. Nuri Taner. İstanbul: Artsan Yay., ss. 25-29.

BEN-AMOS, Dan (2007). "Halk Bilgisinin (Folklorun) Bağlamı: İmalar ve Beklentiler". Milli Folklor. S. 76, (Kış-2007), ss. 232-243.

BEŞİROV, Gomer (1965). "T11sımnar Dönyasında." Gomer Beşirov Saylanma Eserler, II Tom-Hikayeler, Povest, Publitsistika. Kazan: Tatarstan Kitap Neşriyat1, ss. 233-247.

BORATAV, Pertev Naili (1988). "Masal ve Masalcı Üzerine". Masal Araştırmaları FolktaleStudies I. Haz. Nuri Taner. İstanbul: Art-San Yayınları, ss. 31-39.

CAMALETDİNOV, L. (1977). "Éncé Çeçtém, Éncé Ciyam.” Kazan Utları. Kazan, 3 Mart 1977 (Dış kapakta 1978), ss. 139-146.

CAMALETDINOV, L. Ş. (1988). “Ekiyet Traditsiyesé hem Zaman.” Tatar Halk Poetik İcatının Hezérgé Torışı. Kazan: SSSR Fenner Akademiyesé, Kazan Filial1, ss. 5-24.

ÇOBANOĞLU, Özkul (2000). Asşık Tarzı Kültür Geleneği ve Destan Türü. Ankara: Akçă̆ Yay.

ÇOBANOĞLU, Özkul (2002). Halkbilimi Kuramları ve Araştırma Yöntemleri Tarihine Giriş. Ankara: Akçağ Yay.

DORSON, Richard M. (2006). Günümüz Folklor Kuramları. Çev. Selcan Gürçayır, Yeliz Özay. Ankara: Geleneksel Yay.

EKİCI, Metin (2006). “Türk Sözlü Geleneğinde Anlatıcılar ve Anlatmalar Arasındaki İlişkiye Art Zamanlı (Diyakronik) ve Eș Zamanlı (Senkronik) Bir Bakış." Mitten Meddaha Türk Halk Anlatıları Uluslararası Sempozyum Bildirileri. Yay. Haz. M. Öcal Oğuz, Tuba Saltık Özkan. Ankara: Gazi Üniv., THBMER Yay., 2006, ss. 83-89.

EKİCi, Metin (2007). Halk Bilgisi (Folklor) Derleme ve İnceleme Yöntemleri. Ankara: Geleneksel Yay.

EKİĊ, Metin (2008). “Geleneksel Kültürü Güncellemek Üzerine Bir Değerlendirme." Milli Folklor. S.: 80, (Kış 2008), ss. 33-38.

ERGUN, Pervin (2014). “Türk Masal Anlatıcısının Kimliği”. Milli Folklor. S. 104 (Kış-2014), ss. 33-45.

ESMA Şimşek (2002). "Malatyalı Bir Masal Anası: Suzan Geniş”. Milli Folklor. S. 56 (Kış-2002), ss. 109-120. 
FEDAKÂR, Selami (2011). Özbek Sözlü Geleneğinde Masallar. İzmir: Egetan Yayınları.

GALiULLİN, Telgat (1998). "Stalin Devri Tatar Kültür Hayatı." Türk Dünyası Dil ve Edebiyat Dergisi. Türk Dünyası Dil ve Edebiyat Dergisi. Akt.: Hatice Şirin. S.: 6, Güz 1998, ss. 646-653.

GÜLTEKİN, Mustafa (2010). Tataristan Masalları Üzerinde Bir Araşttrma. Ege Üniversitesi, Sosyal Bilimler Enstitüsü, Türk Halk Bilimi Anabilim Dal, Doktora Tezi. (Bu tezden hareketle hazırlanan "Kazan Tatar Masalları" adlı kitap 2013 yllında AKMB tarafından yayımlanmıştır.)

GÜLTEKİN, Mustafa (2014). "Yerelleşme, Performans ve Beden Folkloru Bağlamında Balıkesirli Masal Anlatıcısı Kezban Karakoç". Milli Folklor. S. 104 (Kış-2014), ss. 46-59.

KECE Bilen Büri. Red. H. Yarmi. Kazan: Tatgosizdat, 1944.

LiNDA, Degh, (1989). Folktales and Society. Story-Telling in A Hunagiran Peasant Community. Translated by Emily M. Schossberger. Bloomington and Indianapolis: Indiana University Pres.

MOSTAFIN, Rafail , Reis Davutov (1997). "Repressiya Kurbanı Tatar Yazarları." Türk Dünyası Dil ve Edebiyat Dergisi. Akt.: Mustafa Öner. S.: 3, Bahar 1997, ss. 135-168.

ÖNAL, Mehmet Naci (2011). Muğla Masalları. Muğla: Muğla Üniversitesi Yayınları.

RAZINN, Gomer (1940). Hallk Ekiyetleri. Kazan: Tatgosizdat.

REİCHL, Karl (2002). Türk Boylarının Destanları (Gelenekler, Şekiller, Şiir Yaplsi). Çev. Metin Ekici, Ankara: TDK Yay.

SAKAOĞLU, Saim (1999a). "Masal Anlatıcılarının Bazı Hususiyetleri”. Masal Araştırmaları. Ankara: Akçağ Yayınları, ss. 130-133.

SAKAOĞLU, Saim (1999b). "Tokatlı Bir Masal Anası: Şahadet Göl”. Masal Araştırmalar. Ankara: Akçağ Yayınları, 1999b: 147-151.

SAKAOĞLU, Saim (2002). Gümüşhane ve Bayburt Masalları. Ankara: Akçağ Yayınları, 2002.

SAKAOĞLU, Saim (2002). Gümüşhane ve Bayburt Masalları. Ankara: Akçağ Yay. 
SARITAŞ, Süheyla (2009). "Halk Anlatılarında Hayat Hikâyesi Unsuru”. Atatürk Üniversitesi Türkiyat Araştırmaları Enstitüsü Dergisi 40, ss. 171-178.

SEVER, Mustafa (2007). “Ziya Gökalp'in Masallarında Tipler.” Milli Folklor. S.: 74, Yaz 2007, ss. 29-33.

SEYIDOĞLU, Bilge (1975). Erzurum Halk Masalları Üzerinde Araştırmalar. Ankara: Baylan Mat.

ŞENOCAK, Ebru (2002). "Malazgirtli Bir Masal Anlatıcısı: Süleyman Gül”. Milli Folklor, S. 53 (Bahar-2002), ss. 94-101.

Tatar Halık Ekiyetleri. Tözüvçileri: G. Beşir, H. Yarmi. Kazan: Tatgosizdat YeşlerBalalar Edebiyatı Sektorı, Kazan:1950 (Dış kapakta 1949).

TíTON, Jeff Todd (2015). "Metin." Halkbiliminde Kuramlar ve Yaklaşımlar 3. Çev.: Öykü Terzioğlu, Yay. Haz. M. Öcal Oğuz vd. Ankara: Geleneksel Yay. ss. 272-289.

YILDIRIM, Dursun (1998). "Türk Folklor Araştırmalarının Problemleri”. Türk Bitiği Araştırma/İnceleme Yazıları. Ankara: Akçağ Yay., ss. 65-75. 
